\title{
Mathematical modelling of the osmotic dehydration of physalis
} Modelagem matemática da desidratação osmótica da physalis

\author{
Fernanda Rosa Assis', Rui Manuel Santos Costa de Morais', Alcina Maria Miranda Bernardo de Morais ${ }^{1 *}$ \\ 1 Universidade Católica Portuguesa (UCP), Centro de Biotecnologia e Química Fina (CBQF), Escola Superior de Biotecnologia, \\ Laboratório Associado, Porto - Portugal
}

\section{${ }^{*}$ Corresponding Author}

Alcina Maria Miranda Bernardo de Morais, Universidade Católica Portuguesa (UCP), Centro de Biotecnologia e Química Fina (CBQF), Escola Superior de Biotecnologia, Laboratório Associado, Campus, Rua Arquiteto Lobão Vital, 172, CEP: 4200-374, Porto - Portugal, e-mail: abmorais@porto.ucp.pt

Cite as: Mathematical modelling of the osmotic dehydration of physalis. Braz. J. Food Technol., v. 21, e2017102, 2018.

Received: July 12, 2017; Accepted: Oct. 19, 2017

\section{Abstract}

Physalis was osmotically dehydrated with $60^{\circ} \mathrm{Bx}$ sucrose or sorbitol solutions at $60^{\circ} \mathrm{C}$ and with a mass ratio of sample to solution of 1:4, at atmospheric pressure or under vacuum at 150 mbar. The Crank's, Peleg's and Page's models were tested to describe the mass transfer kinetics for water loss (WL) and solids gain (SG). The effective diffusivities of both water and solute were around $10^{-11} \mathrm{~m}^{2} \mathrm{~s}^{-1}$ under all conditions. Peleg's model presented the best fit. The use of sorbitol as the osmotic agent resulted in an increase in the WL rate. In experiments with sucrose solutions, a higher WL was obtained under vacuum than at atmospheric pressure. The SG was particularly low during osmotic dehydration. Thus, the use of sorbitol as the osmotic agent was shown to be a promising alternative to sucrose.

Keywords: Physalis; Osmotic dehydration; Sorbitol; Vacuum; Mass transfer; Mathematical models.

\section{Resumo}

Os frutos de Physalis foram desidratados osmoticamente com soluções de sacarose ou sorbitol de $60{ }^{\circ} \mathrm{Bx}, \mathrm{a} 60^{\circ} \mathrm{C}, \mathrm{e}$ com uma razão de massa de amostra para massa de solução de 1:4, à pressão atmosférica ou a uma pressão de vácuo de 150 mbar. Os modelos matemáticos de Crank, Peleg e Page foram testados para descrever as cinéticas de perda de água $(W L)$ e ganho de sólidos (SG). A difusividade efetiva da água e do soluto foi cerca de $10^{-11} \mathrm{~m}^{2} \mathrm{~s}^{-1}$, para todas as condições. O modelo de Peleg apresentou o melhor ajuste. A utilização de sorbitol como agente osmótico resultou num aumento de WL. Nas experiências com soluções de sacarose, foi obtida uma maior WL em vácuo do que à pressão atmosférica. O SG foi particularmente reduzido durante a desidratação osmótica. Em conclusão, o sorbitol mostrou ser uma alternativa promissora à sacarose, enquanto agente osmótico.

Palavras-chave: Physalis; Desidratação osmótica; Sorbitol; Vácuo; Transferência de massa; Modelos matemáticos.

\section{Introduction}

Physalis, or cape gooseberry or golden berry (Physalis peruviana L.) is an exotic fruit which originated in South America, but is currently commercialised in several tropical and subtropical countries (IZZLI et al., 2014; SALAZAR et al., 2008; YILDIZ et al., 2015). The berries are annual or short-lived perennial and the plant can grow to up to $1.8 \mathrm{~m}$. The fruit is protected by an accrescent calyx and covered by a brilliant yellow peel (PUENTE et al., 2011).
The interest in physalis increased due to its nutritional composition and the presence of biologically active compounds that provide health benefits due to medicinal properties such as antispasmodic, diuretic, antiseptic, sedative, analgesic and antidiabetic activities (MUNIZ et al., 2015; PUENTE et al., 2011; SALAZAR et al., 2008). The fruit contains $15 \%$ soluble solids, mainly sugars, and is an excellent source of bioactive compounds such as provitamin A, vitamin C, iron and some of 
the B-complex vitamins (RAMADAN, 2011; SALAZAR et al., 2008). The production of physalis has increased in recent years, but it is a highly perishable fruit with a recommended commercialization period of 12 hours after harvest, otherwise requiring special storage conditions (LUCHESE et al., 2015).

Osmotic dehydration (OD) allows for the preservation of fruits by reducing the initial water content by up to $50 \%$. The osmotic agent most frequently used in the OD of fruits is sucrose because of its effectiveness, convenience and desirable flavour (LENART, 1996), although other solutes have been used in the osmotic process, such as sorbitol (BROCHIER et al., 2015; CHAUHAN et al., 2011; RODRÍGUEZ et al., 2013). Sorbitol is a prebiotic with proven health properties (CHANDRA; KUMARI, 2015; CHAUHAN et al., 2011; PATEL; GOYAL, 2012). The beneficial health effects of prebiotics are associated with gut health maintenance, the prevention of colitis, inhibition of cancer, immune-potentiaton, the reduction of cardiovascular disease, the prevention of obesity and constipation, and the production of bacteriocins (PATEL; GOYAL, 2012). In addition, sorbitol is less caloric and has a relative sweetness of around $60 \%$ as compared to sucrose (SILVEIRA; JONAS, 2002).

Different models have been proposed with the objective of predicting the mass transfer kinetics of the OD process, and they may be classified as empirical, semi-empirical, mechanistic and phenomenological (ASSIS et al., 2016). A few studies have been published on the application of this technology to physalis (LUCHESE et al., 2015).

The objectives of this study were: i) to carry out the osmotic dehydration of physalis, using sucrose and sorbitol as the solutes $\left(60^{\circ} \mathrm{Bx}\right)$, with a mass ratio of sample to solution of $1: 4$ and temperature of $60^{\circ} \mathrm{C}$, and study the effect of the pressure (1 bar and 150 mbar) on the mass transfer kinetics of $W L$ and $S G$; ii) to test the adequacy of the fit of some mathematical models (Crank's, Peleg's, Page's) to describe the WL and SG of the fruit.

\section{Material and methods}

\subsection{Samples}

Physalis (Physalis peruviana L.) with diameters of $15.7 \pm 2.7 \mathrm{~mm}$ were purchased from a local market and stored at $4{ }^{\circ} \mathrm{C}$. The fruits were washed and sanitized for 5 minutes in an aqueous solution containing 7500 ppm active chlorine. The soluble solids content of the physalis was determined using a hand refractometer (Atago, China) and the water activity using the equipment Aqualab Series 3 (Decagon Devices Inc., Pullmam, Washington, USA).

All determinations were carried out in triplicate.

\subsection{Osmotic dehydration}

The experiments were carried out at atmospheric pressure and under vacuum. The osmotic solutions were prepared with ultra-pure water and sucrose or sorbitol (Fagron Iberica, Spain) at $60^{\circ} \mathrm{Bx}$. The physalis fruits were immersed in the osmotic solution in Erlenmeyer flasks (250 $\mathrm{mL}$ ) for the experiments at atmospheric pressure, or in vacuum containers for the vacuum treatment (Lacor, Spain). The experiments were carried out using a 1:4 mass ratio of sample to solution. A vacuum of 150 mbar was established through the septum in the vacuum containers using a vacuum diaphragm pump (Vacuubrand ME 4C NT, Lab Unlimited, UK). The vessels were placed in a floor standing shaking incubator (SI-300C, Wiggenhauser, Germany) and shaken at $50 \mathrm{rpm}$ and $60^{\circ} \mathrm{C}$.

Samples (approximately $3 \mathrm{~g}$ ) were removed from the solution after different time intervals (every 2 hours for the first 10 hours, and then every 5 hours up to 30 hours). The samples were rinsed with ultra-pure water to remove the solution adhered to the surface and blotted with tissue paper to remove the excess of water from the surface.

\subsection{Osmotic dehydration parameters and mathematical models}

The parameters of water loss $(W L)$ and sugar gain $(S G)$ were determined respectively using the following Equations 1 and 2:

$$
\begin{aligned}
& W L=\frac{w_{w 0}-w_{w}}{w_{0}} \\
& S G=\frac{w_{s}-w_{s 0}}{w_{0}}
\end{aligned}
$$

where $w_{w o}$ is the initial moisture content, $w_{w}$ is the moisture content at time $t, w_{0}$ is the initial weight of the sample, $w_{s}$ is the solids content at time $t$ and $w_{s 0}$ is the initial solids content of the sample, all in $\mathrm{g}$.

The Crank's, Peleg's and Page's models were used to fit the experimental data.

\subsubsection{Crank's model}

In the present work, mathematical solutions to problems of unidirectional diffusion in the unsteady state were considered for the geometry of a sphere. In this case the diffusion is radial and $W L$ and $S G$ were calculated using the following Equation 3:

$$
\frac{W L}{W L_{\infty}} \text { or } \frac{S G}{S G_{\infty}}=1-\frac{6}{\pi^{2}} \sum_{n=1}^{\infty} \frac{1}{n^{2}} \exp \left(-n^{2} \cdot \pi^{2} \cdot D_{e} \cdot \frac{t}{r^{2}}\right)
$$

where $W L_{\infty}$ and $S G_{\infty}$ are, respectively, the values for water loss and solids gain at equilibrium; $D_{e}$ is the effective diffusivity of water or solute; and $r$ is the average radius of the fruit $(7.85 \pm 1.35 \mathrm{~mm})$.

\subsubsection{Peleg's model}

$W L$ and $S G$ were calculated using the following Equation 4:

WLor SG $=\frac{t}{k_{1}+k_{2} \cdot t}$ 
where $k_{1}$ and $k_{2}$ are the Peleg's constants for $W L$ and $S G$, respectively.

\subsubsection{Page's model} Equation 5:

WL and SG were calculated using the following

$\frac{W L}{W L_{\infty}}$ or $\frac{S G}{S G_{\infty}}=1-\exp \left(-A . t^{B}\right)$

where $A$ and $B$ are the Page's constants for $W L$ and $S G$, respectively.

\subsection{Moisture content}

The moisture content of physalis was determined by drying in an oven (FP115, Binder, Tuttlingen, Germany) at $105^{\circ} \mathrm{C}$ to constant weight (HORWITZ, 2002). The determinations were carried out in triplicate.

\subsection{Statistical analysis}

The statistical analysis was carried out using Microsoft Excel 2000 (Microsoft Corporation, USA) and IBM SPSS ${ }^{\circledR}$ Statistics 20.0 for Windows ${ }^{\circledR}$ (2012, SPSS Inc., Chicago, USA).

The model parameters were estimated by non-linear regression procedures and the margin of error of the estimates calculated at 95\% (margin of error = half the width of the confidence interval at 95\%). The regressions were also assessed by ANOVA. The adequacy of each model fit was evaluated from the determination coefficient $\left(\mathrm{R}^{2}\right)$ and by the analysis of the residuals. The randomness and homoscedasticity of the residuals were assessed by a visual inspection of their dispersion vs. the values predicted by the model. The normality of the residuals was evaluated using the Kolmogorov-Smirnov test.

All the tests and analyses were carried out with a significance level of $5 \%$.

\section{Results and discussion}

The soluble solids content, moisture content and water activity values of the fresh physalis were $15 \pm 2^{\circ} \mathrm{Bx}$, $4.645 \pm 0.220 \mathrm{~kg}$ water $\mathrm{kg}^{-1} \mathrm{DM}$ and $0.988 \pm 0.003$, respectively. During the osmotic dehydration of most fruits, a rapid water loss can be noted during the first two hours of the process (ASSIS et al., 2017; SILVA et al., 2012). However, physalis did not present this behaviour. In Figure 1 a low rate of $W L$ can be observed in the early phase of the process. This can be explained by the low permeability to fluid exchange of the surface of physalis (PUENTE et al., 2011; RAMADAN, 2011). Under the experimental conditions used for the OD of physalis, a low solute gain was observed during the whole process, besides presenting great variability of the data. Luchese et al. (2015) observed the same behaviour during the OD of physalis at $40{ }^{\circ} \mathrm{C}$ with $40 \%$ and $70 \%$ sucrose concentrations. This may be explained by the low permeability of the periderm of the fruit. The De values of the water and of the solute during the OD process were calculated using the four terms of Equation 3. Table 1 shows the values obtained for this parameter and for $\mathrm{R}^{2}$. The values for the De of $W L$ were between $3.34 \times 10^{-11}$ and $8.69 \times 10^{-11} \mathrm{~m}^{2} \mathrm{~s}^{-1}$. These values are close to those $\left(1.4\right.$ and $\left.2.9 \times 10^{-10} \mathrm{~m}^{2} \mathrm{~s}^{-1}\right)$ obtained by Luchese et al. (2015) in the OD of physalis. No difference in De was observed for the different osmotic agents and pressures used. With respect to the $S G$, the $R^{2}$-values of the fit were rather low, but the other assumptions for the adequacy of the models (residual values normally distributed and distributed randomly around zero) were satisfied. The De values obtained for the $S G$ varied from $2.56 \times 10^{-11}$ to $5.40 \times 10^{-11} \mathrm{~m}^{2} \mathrm{~s}^{-1}$. No significant differences were observed between the De of samples submitted to the different conditions, due to the high margins of error of the values.

The Peleg's and Page's models were able to describe the mass transfer kinetics of the osmotic dehydration of physalis well under the conditions used. Thus, the best

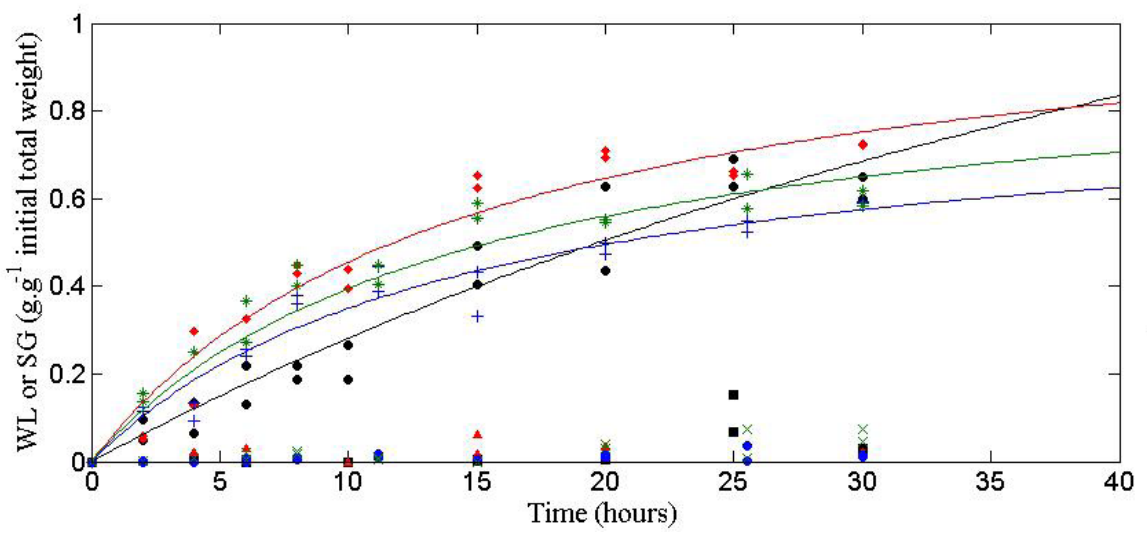

- WL OD sucrose, 1013 mbar

- WL OD sorbitol, $1013 \mathrm{mbar}$

+ WL OD sucrose, 150 mbar

* WL OD sorbitol, $150 \mathrm{mbar}$

- SG OD sucrose, 1013 mbar

- SG OD sorbitol, 1013 mbar

- SG OD sucrose, 150 mbar

$\times \quad$ SG OD sorbitol, 150 mbar

Fit Peleg's model

Figure 1. Experimental data and fit of Peleg's model for the WL and SG of physalis osmotically dehydrated in sucrose or sorbitol solutions at atmospheric pressure or under vacuum (150 mbar) at $60{ }^{\circ} \mathrm{C}$. 
Mathematical modelling of the osmotic dehydration of physalis

Assis, F. R. et al.

Table 1. Fits of the Crank's and Peleg's models for mass transfer during the OD of physalis at atmospheric pressure or under vacuum

\begin{tabular}{|c|c|c|c|c|c|c|c|c|c|}
\hline \multirow{3}{*}{$\begin{array}{c}\mathrm{T} \\
\left({ }^{\circ} \mathrm{C}\right)\end{array}$} & \multirow{3}{*}{ Solute } & \multirow{3}{*}{$\begin{array}{c}\text { Pressure } \\
\text { (mbar) }\end{array}$} & \multicolumn{4}{|c|}{ Crank's model } & \multirow{2}{*}{\multicolumn{3}{|c|}{$\begin{array}{c}\text { Peleg's model } \\
W L\end{array}$}} \\
\hline & & & \multicolumn{2}{|l|}{$W L$} & \multicolumn{2}{|l|}{ SG } & & & \\
\hline & & & $\begin{array}{l}D_{e} \times 10^{11} \pm \text { margin } \\
\text { of error }\left(\mathrm{m}^{2} \mathrm{~s}^{-1}\right)\end{array}$ & $\mathbf{R}^{2}$ & $\begin{array}{l}D_{e} \times 10^{11} \pm \text { margin } \\
\text { of error }\left(\mathrm{m}^{2} \mathrm{~s}^{-1}\right)\end{array}$ & $\mathbf{R}^{2}$ & $\begin{array}{l}k_{1} \pm \text { margin of } \\
\text { error }\left(h \mathbf{~ k g ~ k g}^{-1}\right)\end{array}$ & $\begin{array}{l}k_{2} \pm \text { margin of } \\
\text { error }\left(\mathbf{k g ~ k g}^{-1}\right)\end{array}$ & $\mathbf{R}^{2}$ \\
\hline 60 & sucrose & 1013 & $3.34 \pm 11.52$ & 0.746 & $2.56 \pm 25.45$ & 0.420 & $31.266 \pm 8.734$ & $0.417 \pm 0.386$ & 0.939 \\
\hline 60 & sucrose & 150 & $5.09 \pm 9.49$ & 0.873 & $3.08 \pm 46.68$ & 0.161 & $16.792 \pm 1.179$ & $1.179 \pm 0.246$ & 0.954 \\
\hline 60 & sorbitol & 1013 & $5.44 \pm 10.69$ & 0.860 & $5.40 \pm 103.28$ & 0.089 & $12.983 \pm 3.115$ & $0.897 \pm 0.179$ & 0.946 \\
\hline 60 & sorbitol & 150 & $8.69 \pm 17.47$ & 0.922 & $2.83 \pm 20.46$ & 0.452 & $14.863 \pm 1.044$ & $1.044 \pm 0.510$ & 0.773 \\
\hline
\end{tabular}

Margin of error is half the width of the confidence interval at $95 \%$.

fit was selected based on the precision of the parameter estimation, calculated from the Standard Half Width (SHW = margin of error/ parameter value) at 95\% confidence. The Peleg's model described the kinetics of the OD of physalis with the highest precision of parameter estimates (i.e. lowest SHW) for all the conditions used (Table 1). The values for WL and the fit of the Peleg's model for the $W L$ of physalis osmotically dehydrated in $60^{\circ} \mathrm{Bx}$ sucrose or sorbitol solutions at atmospheric pressure or under vacuum (150 mbar) at $60{ }^{\circ} \mathrm{C}$, and using a mass ratio of sample to solution of 1:4, are presented in Figure 1.

Since the parameter $k$ is related to the initial mass transfer rate during OD, it can be observed that the initial rate of $W L$ was higher in experiments with sorbitol (lower $k$ ), although the equilibrium values were not significantly different between the two solutes. When different pressures were used, significant differences were noted only in experiments using the sucrose solution. Thus, it was observed that the initial rate of $W L$ in the OD under vacuum was higher than at atmospheric pressure, and the equilibrium value $\left(W L_{\infty}\right)$ was lower.

Since the Page's and Peleg's models could not describe the $S G$ at either atmospheric pressure or vacuum pressure, the fits were not shown.

\section{Conclusion}

The Crank's, Peleg's and Page's models fitted the values for the water content of physalis well during osmotic dehydration. The effective diffusivities of the water and solute of the fruit during this process were about $10^{-11} \mathrm{~m}^{2} \mathrm{~s}^{-1}$, and the osmotic agent and pressure used did not affect this parameter.

The use of sorbitol can accelerate the initial rate of water loss (WL). Therefore the use of sorbitol as the osmotic agent in OD is a promising alternative to replace sucrose. The use of vacuum only increased the rate of $W L$ in physalis osmotically dehydrated with a sucrose solution.

\section{Acknowledgements}

This work was supported by the FCT (Fundação para a Ciência e Tecnologia - Science \& Technology Foundation) National Fund through project UID/Multi/50016/2013.
The first author acknowledges the financial support of CAPES (1528/13-0).

\section{References}

ASSIS, F. R.; MORAIS, R. M. S. C.; MORAIS, A. M. M. B. Mass transfer in osmotic dehydration of food products: comparison between mathematical models. Food Engineering Reviews, v. 8, n. 2, p. 116-133, 2016. http://dx.doi.org/10.1007/s12393015-9123-1.

ASSIS, F. R.; MORAIS, R. M. S. C.; MORAIS, A. M. M. B. Mathematical modelling of osmotic dehydration kinetics of apple cubes. Journal of Food Processing and Preservation, v. 41, n. 3, p. e12895, 2017. http://dx.doi.org/10.1111/jfpp.12895.

BROCHIER, B.; MARCZAK, L. D. F.; NOREÑA, C. P. Z. Osmotic dehydration of yacon using glycerol and sorbitol as solutes: water effective diffusivity evaluation. Food and Bioprocess Technology, v. 8, n. 3, p. 623-636, 2015. http://dx.doi.org/10.1007/ s11947-014-1432-5.

CHANDRA, S.; KUMARI, D. Recent development in osmotic dehydration of fruit and vegetables: a review. Critical Reviews in Food Science and Nutrition, v. 55, n. 4, p. 552-561, 2015. PMid:24915357. http://dx.doi.org/10.1080/10408398.2012.664830.

CHAUHAN, O. P.; SINGH, A.; SINGH, A.; RAJU, P. S.; BAWA, A. S. Effects of osmotic agents on colour, textural, structural, thermal, and sensory properties of apple slices. International Journal of Food Properties, v. 14, n. 5, p. 1037-1048, 2011. http://dx.doi.org/10.1080/10942910903580884.

HORWITZ, W. (Ed.). Official methods of analysis of the Association of Official Analytical Chemists. Gaithrsburg: AOAC, 2002.

İZLI, N.; YILDIZ, G.; ÜNAL, H.; IŞIK, E.; UYLAȘER, V. Effect of different drying methods on drying characteristics, colour, total phenolic content and antioxidant capacity of Goldenberry (Physalis peruviana L.). International Journal of Food Science \& Technology, v. 49, n. 1, p. 9-17, 2014. http://dx.doi.org/10.1111/ ijfs. 12266.

LENART, A. Osmo-convective drying of fruits and vegetables: technology and application. Drying Technology, v. 14, n. 2, p. 391-413, 1996. http://dx.doi.org/10.1080/07373939608917104. 
LUCHESE, C. L.; GURAK, P. D.; MARCZAK, L. D. F. Osmotic dehydration of physalis (Physalis peruviana L.): evaluation of water loss and sucrose incorporation and the quantification of carotenoids. Lebensmittel-Wissenschaft + Technologie, v. 63, n. 2, p. 1128-1136, 2015. http://dx.doi.org/10.1016/j.Iwt.2015.04.060.

MUNIZ, J.; MOLINA, A. R.; MUNIZ, J. Physalis: productive and economic overview in Brazil. Horticultura Brasileira, v. 33, n. 2, p. 1, 2015.

PATEL, S.; GOYAL, A. The current trends and future perspectives of prebiotics research: a review. 3 Biotech, v. 2, n. 2, p. 115-125, 2012. http://dx.doi.org/10.1007/s13205-012-0044-x.

PUENTE, L. A.; PINTO-MUÑOZ, C. A.; CASTRO, E. S.; CORTÉS, M. Physalis peruviana Linnaeus, the multiple properties of a highly functional fruit: a review. Food Research International, v. 44, n. 7, p. 1733-1740, 2011. http://dx.doi.org/10.1016/j. foodres.2010.09.034.

RAMADAN, M. F. Bioactive phytochemicals, nutritional value, and functional properties of cape gooseberry (Physalis peruviana): an overview. Food Research International, v. 44, n. 7, p. 18301836, 2011. http://dx.doi.org/10.1016/j.foodres.2010.12.042.

RODRÍGUEZ, M. M.; ARBALLO, J. R.; CAMPAÑONE, L. A.; COCCONI, M. B.; PAGANO, A. M.; MASCHERONI, R. H. Osmotic dehydration of nectarines: Influence of the operating conditions and determination of the effective diffusion coefficients. Food and Bioprocess Technology, v. 6, n. 10, p. 2708-2720, 2013. http://dx.doi.org/10.1007/s11947-012-0957-8.

SALAZAR, M. R.; JONES, J. W.; CHAVES, B.; COOMAN, A. A model for the potential production and dry matter distribution of cape gooseberry (Physalis peruviana L.). Scientia Horticulturae, v. 115, n. 2, p. 142-148, 2008. http://dx.doi.org/10.1016/j. scienta.2007.08.015.

SILVA, M. A. C.; SILVA, Z. E.; MARIANI, V. C.; DARCHE, S. Mass transfer during the osmotic dehydration of West Indian cherry. Lebensmittel-Wissenschaft + Technologie, v. 45, n. 2, p. 246-252, 2012. http://dx.doi.org/10.1016/j.Iwt.2011.07.032.

SILVEIRA, M.; JONAS, R. The biotechnological production of sorbitol. Applied Microbiology and Biotechnology, v. 59, n. 4-5, p. 400-408, 2002. PMid:12172602. http://dx.doi.org/10.1007/ s00253-002-1046-0.

YILDIZ, G.; İZLI, N.; ÜNAL, H.; UYLAŞER, V. Physical and chemical characteristics of goldenberry fruit (Physalis peruviana L.). Journal of Food Science and Technology, v. 52, n. 4, p. 2320-2327, 2015. PMid:25829615. http://dx.doi.org/10.1007/ s13197-014-1280-3. 